\title{
Profile of depigmenting cosmetics and dermatological products on the market
}

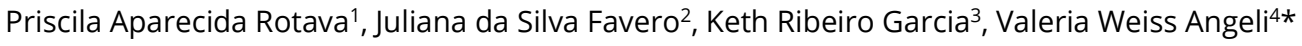 \\ ${ }^{1}$ Faculdade de Farmácia, Universidade de Caxias do Sul (UCS), Caxias do Sul, RS, Brasil \\ ${ }^{2}$ Centro Universitário da Serra Gaúcha (FSG), Caxias do Sul, RS, Brasil \\ ${ }^{3}$ Universidade Federal do Rio Grande do Sul (UFRGS), Porto Alegre, RS, Brasil \\ ${ }^{4}$ Centro de Ciências Biológicas e da Saúde (CCBS), Faculdade de Farmácia, Universidade de Caxias do Sul (UCS), Caxias do Sul, \\ RS, Brasil \\ *Corresponding author: vwangeli@ucs.br
}

\begin{abstract}
The skin is the largest and most exposed organ of the human body, therefore subject to diseases and alteration of its appearance. Among these alterations, the cutaneous hyperchromia may be cited. Currently, the market offers numerous products with depigmenting action to the treatment of such disorders. The aim of this work was to analyze depigmenting products commercialized in establishments in the city of Bento Gonçalves (RS, Brazil) and websites of cosmetic companies. It was found 45 products with depigmenting action and, from these, 59 different active agents were identified. The main active compounds found were kojic acid, arbutin, ascorbic acid, hydroquinone and glycolic acid. Another observed data was that in $78 \%$ of the studied products the active substances were being used in combination. The most used vehicles were also studied as a reference to the use of sunscreen in the treatment of cutaneous hyperchromia. The present work had identified in the market a variety of products with depigmentation action and, because of this, it aims to serve as a reference to the healthcare professionals, especially at the prescribing moment, looking for the best results, with regards to treatment efficiency and safety.
\end{abstract}

Keywords: Cosmetic. Depigmenting. Hyperchromia.

\section{How to cite}

Rotava PA, Favero JS, Garcia KR, Weiss-Angeli V. Profile of depigmenting cosmetics and dermatological products on the market. Rev Ciênc Farm Básica Apl. 2020;41:e643.

https://doi.org/10.4322/2179-443X.0643

\section{INTRODUCTION}

The skin is the largest organ of human body, being the most exposed and, therefore, the most subjected to infections, diseases and appearance alterations (Tortora \& Derrickson, 2012). The skin acts as a body protection cover, controlling body fluids lost and avoiding the penetration of strange and noxious substances in the organism (Baron \& Skazik, 2010).

Melanocytes are cells found in the epidermis responsible for melanin production, process known as melanogenesis. Melanin is a heterogeneous biopolymer responsible for skin, hair and eyes pigmentation. Furthermore, melanin is also responsible for photoprotection, diffracting or reflecting ultraviolet radiation (Costin \& Hearing, 2007). 
Melanogenesis is regulated by the enzyme tyrosinase, synthesized in the rough endoplasmic reticulum of the melanocyte, and then transferred to its Golgi complex. The enzyme tyrosinase oxidizes tyrosine to dihydroxyphenylalanine (DOPA) and this one oxidizes to dopaquinone in which these chemical reactions occur in melanosomes. When melanosomes are filled with pigment, melanocytes transfer the melanosomes to keratinocytes where they are metabolized. The presence or absence of cysteine determines feomelanin (yellow/red pigment) or eumelanin (brown/black pigment) formation (Miot et al., 2007). Figure 1 shows a scheme of melanin synthesis.

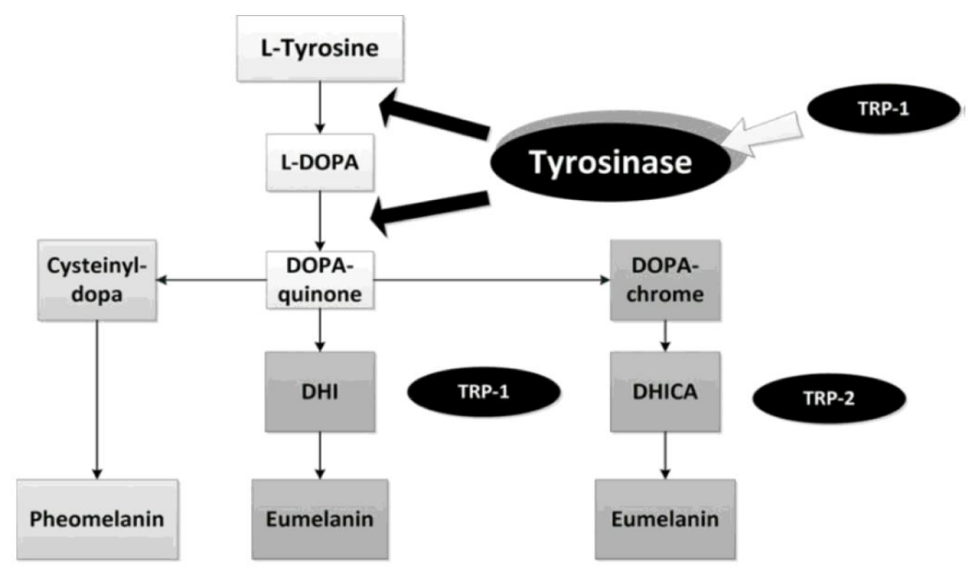

Figure 1: Melanogenesis representative scheme. DOPA (dihydroxyphenylalanine); DHI (dihydroxyindole); DHICA (2 carboxilic acid dihydroxyindole); TRP (tyrosinase-related protein)

(Videira et al., 2013).

Melanogenesis is a process that can suffer interferences by different factors, such as genetic, hormonal and physical (ultraviolet radiation) factors. In addition, the use of facial and body moisturizers, beautification or cutaneous medical treatments may also influence this process (Costin \& Hearing, 2007). Among the aforementioned factors, the skin exposure to ultraviolet radiation can cause hyperpigmentation disorders, photoaging, suntan and photocarcinogenesis (Costin \& Hearing, 2007).

The disorganized melanin production may lead to possible dyschromia, which contributes to cutaneous hypo- or hyper- pigmentations, which characteristics differ between each other, considering the appearance, treatment and/or visual aspects (Brenner \& Hearing, 2009). Hyperpigmentation, also called hyperchromia, results of the excess of melanin production and pigment accumulation, resulting in areas where the skin will have a darker shade. It usually occurs with higher frequency than hypopigmentation, known as hypochromia (deficiency in melanin production) (Marques et al., 2011). Melasma and postinflammatory hyperpigmentation are examples of the cutaneous hyperchromia. The melasma is related to hormonal changes and manifests, use of oral contraceptives, a combination of other triggers such as sun exposure, genetic factors including skin type, and other unknown factors (Gold \& Biron, 2011).

Several substances are currently used for hyperchromia treatment, and may be used alone or in combination with other substances. Examples are: hydroquinone, arbutin (natural b-glycoside of hydroquinone) or arbutin-rich plant extracts. Depigmenting or skin whitening agents act by different mechanisms and are available in the market in several presentation forms, such as gels, lotions, etc (Marques et al., 2011; Gold \& Biron 2011). The most common mechanism of depigmenting agents is to reduce or inhibit the enzyme tyrosinase, thereby diminishing melanin synthesis (Balbinot \& Agnes, 2012).

Based on what has been already presented, the goal of this study was to perform a research on drugstores in the city of Bento Gonçalves (RS, Brazil) and on websites of cosmetic 
products, in order to identify which are the main depigmenting agents used on products with bleaching action available on the market.

\section{MATERIALS AND METHODS}

The search for products with depigmenting action was carried out in pharmacies and drugstores in the city of Bento Gonçalves, RS, Brazil, where 14 establishments were visited. The search for the products were also carried out on the internet, on websites of national and international brands of cosmetics. Data search was performed on Lilacs, Medline, Pubmed, Scielo, and others databases. The keywords applied were: depigmenting, hyperchromia, kojic acid, arbutin, ascorbic acid, hydroquinone and glycolic acid. Priority was given to the use of articles published between the years 2010 and 2018 however; older articles were also used due to their consecrated information.

This study was characterized by being an exploratory descriptive research and for data collection, it was used the software Excel 14.4.5.

\section{RESULTS}

Altogether 45 products were found presenting depigmenting action and may or may not have combined functions. There were 45 products evaluated, in which 8 of them were classified as drugs. The others 37 remained products were evaluated and classified as cosmetics.

Composition analysis of depigmenting products were evaluated in this study and it allowed to evidence the presence of 59 different active substances. Among them, the most recurrent active substances found are listed in Table 1.

Table 1. Majority of active substances described on researched products labels.

\begin{tabular}{cc}
\hline Depigmenting actives (INCI name) & Frequency (\%) \\
\hline Kojic acid & 23.8 \\
Arbutin & 18.0 \\
Ascorbic acid & 13.7 \\
Hydroquinone & 11.9 \\
Glycolic acid & 11.9 \\
\hline
\end{tabular}

The combination of two or more active substances with depigmenting action was verified in $78 \%$ of the studied products and, only $22 \%$ presented an isolated active substance (Figure 2 ).

\section{Actives Association (\%)}

- one active $n$ two actives substances $\|$ three active substances

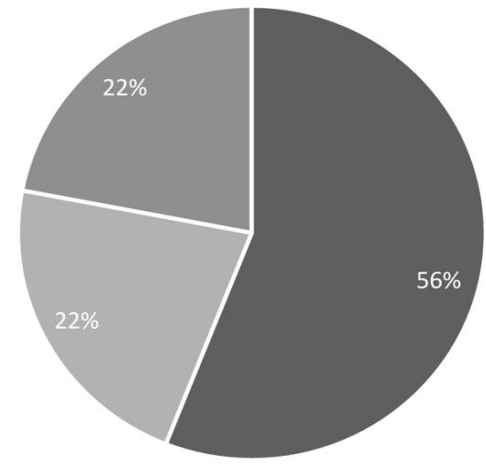

Figure 2: Percentage of active substances associated or not in the consulted products. 
Considering that products performance may be related to the vehicle in which the active substance is incorporated, it was also analyzed the most frequent vehicles among the studied products. According to Figure 3 , it is possible to observe that creams were the most used vehicles (58\%) followed by cream gel, serum and hydrophilic gel.

\section{Vehicles}

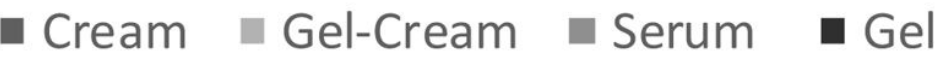

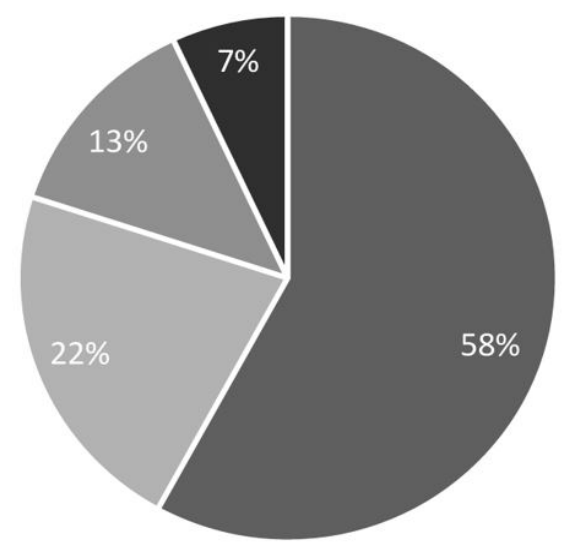

Figure 3: Percentage of used vehicles on studied products.

By analyzing the contained information in studied products' labels, it was possible to identify among the 45 found products, that $71 \%$ had additional functions related in the label. This includes anti-aging ( $20 \%$ of the products) and sunscreen protection factor ( $26 \%$ of the products) indication.

\section{DISCUSSION}

The information of evaluated products was analyzed from the labels and are discussed hereinafter.

\subsection{Regulatory aspects}

There were 45 products evaluated, in which 8 of them were classified as drugs. This observation was possible due to secondary packaging label analysis, such as MS (MS: Ministério da Saúde Health Ministry) registration number, whose numeration begins with the digit "1". According to National Health Surveillance Agency (Agência Nacional de Vigilância Sanitária - ANVISA), drug registration numbers are composed of the abbreviation MS followed by thirteen digits and the first digit is the one that will classify the product, e.g., 1.2700.0002.001-9 for drugs, 2.1888.0006.001-7 for cosmetics and 6.2109.0008.001-1 for food products. The remaining digits refer to the enterprise operation authorization - AFE (five first digits), product (four next digits) and product presentation (three next digits) and verification code (last digit) (Brasil, 2010).

The others 37 remained products were evaluated and classified as cosmetics by the label observing with the MS registration number beginning with the digit " 2 " or the MS abbreviation followed by RDC 343/2005, current legislation in the research's period (Brasil, 2005b).

RDC 67, from October $8^{\text {th }}, 2007$, defines drug as a pharmaceutical product, obtained for prophylactic, curative, palliative or diagnostic purposes (Brasil, 2007). On the other hand, according to RDC 211 , from July $14^{\text {th }}, 2005$, cosmetics are intended for skin, nails and hair's 
protection or beautification (Brasil, 2005a). Therefore, drugs can modify the skin physiology and require studies to prove their efficacy and safety, while cosmetics acts on skin surface not causing physiology modifications.

RDC 7, from February $10^{\text {th }}, 2015$, classifies cosmetics as grade 1 or 2 products. According to the resolution, depigmenting cosmetics are classified as grade 2 products being necessary to establish safety and efficacy's evidences, as well as product information about care and use (Brasil, 2015).

\subsection{Active substances}

According the dates showed in the Table 1, Kojic acid, Arbutin, Ascorbic acid, Hydroquinone, Glycolic acid were the substances that most appreciated in the evaluated products;

\subsubsection{Kojic acid}

It was found kojic acid (5-hydroxy-2-hydroxymethyl-4H-pyran-4-one) in 14 products. It is an antimicrobial substance produced by fungi and bacteria such as Acetobacter, Aspergillus and Penicillium species. Kojic acid is a potent and non-cytotoxic depigmenting agent generally used at concentrations between 1 to 3\%. It acts inhibiting tyrosinase by ions chelation and, consequently, inhibiting melanogenesis (Monteiro et al., 2013). The Scientific Committee on Consumer Products concluded that the use of kojic acid at a maximum concentration of $1.0 \%$ in skin care formulations poses a risk to the health of the consumer (Scientific Committee on Consumer Products, 2008). For safety reasons, kojic acid is banned in cosmetic products in certain countries such as Japan, Korea, and Switzerland (Gold \& Biron, 2011).

The advantage of using kojic acid is due to the softness on the skin, since it does not cause skin irritation nor photo sensibility, so it can be used during daytime. It is easily incorporated into formulations, although it presents some instability due to oxidation becoming gradually yellow or brown in oxygen presence. This degradation may be avoided by the addition of chelators and antioxidants (Gonchoroski \& Corrêa, 2005).

Apart from the whitening action on the skin, it is also known to have photo protective, anti-inflammatory and analgesic actions. It is usually used combined with other depigmenting agents, e.g. glycolic acid (Costa et al., 2012). Kojic acid secondary effects are erythema, skin sensitization and contact dermatitis however, Monteiro et al. (2013) presented that any of the evaluated patients on their study exhibited the cited effects, only one patient reported a burning sensation.

\subsubsection{Arbutin}

Arbutin is a depigmenting agent derived from hydroquinone and naturally occurs in some plant families, such as Lamiaceae, Ericaceae and Rosaceae. It competitively inhibits tyrosinase by cupper atom interaction at the enzyme's center, being capable of suppressing melanin biosynthesis. It was reported in the literature safety tests on use of this active substance for cosmetic preparation, however, there have been studies using animals that have revealed toxic effects at hepatic, renal and carcinogenic level (Costa et al., 2010; Lopes, 2015; Uchida et al., 2014). Among the studied products, 10 presented arbutin as active substance.

\subsubsection{Ascorbic acid}

Ascorbic acid, also known as vitamin C, was found in 8 products. It is one of the oldest active substances with depigmenting function. It was originally obtained from citric fruits such as orange, lemon and acerola. Its action's mechanism blocks tyrosinase and keeps melanin in reduced and bleached form besides its tonic and restructuring skin action. It also inhibits free radical formation, stimulating collagen and fibroblasts synthesis, preventing aging signs. Ascorbic acid has low stability in topical formulations and emulsions water phase in addition to skin penetration difficulty, which may limit its use (Neves, 2013). 
The National Health Surveillance Agency (ANVISA) provided in 2001, and later updated in 2004, the Technical Opinion $n^{\circ} 3$, which guides about acid ascorbic use in cosmetics. This Technical Opinion was elaborated considering the active substance use increasing for the purpose of whitening, antioxidant and collagen synthesis stimulant. Cosmetic products containing ascorbic acid and its derivatives are now classified as grade 2 and their safety and efficacy to use in humans must be proven (Brasil, 2001).

\subsubsection{Hydroquinone}

Hydroquinone is a phenolic derivative in the form of colorless or white crystals, with a sweet taste, incompatible with alkalis, ferric salts and oxidizing agents. Considered reference as depigmenting agent, it is the most prescribed active substance by dermatologists to the treatment of hyperpigmentations (Frasson \& Canssi, 2009; Gaedtke, 2011).

Depigmentation with hydroquinone is not immediate because its mechanism mainly interferes in melanin production, inhibiting enzyme tyrosinase activity and causing melanocyte cytotoxicity. Because it is a water-soluble substance, it is easily incorporated into formulations, although, it rapidly oxidizes when in contact with air becoming brown. Its usual concentration in formulations is from $2 \%$ to $10 \%$ and its effectiveness is proportional to its concentration. It can cause skin irritation and photosensitization in all concentrations (Frasson \& Canssi, 2009; Gaedtke, 2011).

If used in doses up to $300 \mathrm{mg} / \mathrm{kg}$ is not toxic for fetal formation, however this drug is classified as category $C$ by the Food and Drug Administration (FDA), and as grade 2 according to ANVISA. Thus, products containing hydroquinone should be used properly and carefully (Brasil, 2015; Reszko et al., 2009).

Obtained depigmentation is reversible. Discontinuation of treatment may simply lead to melanin synthesis again. The effect usually occurs after one month, and it should not last longer than three months (Gaedtke, 2011). In recent years, use of hydroquinone has become controversial, leading to its withdrawal from European and parts of Asian market (Food and Drug Administration, 2006). The reason was the increasing ochronosis report numbers, therefore, the mechanism of hydroquinone-induced ochronosis remains unknown (Reszko et al., 2009). Among the researched products, 6 contained hydroquinone in their formulation being three products used as unique active substance.

\subsubsection{Glycolic acid}

Glycolic acid was identified in 6 of the forty-five researched products. The substance is an alpha-hydroxy acid extracted from sugar cane. It acts as chemical exfoliator promoting the superficial cell renewal and dispersing melanin on epidermis basal layer thus, increasing depigmenting agents skin penetration. It also improves the texture, tonus and skin tone uniformity. It is usually used in concentration between 50 to $70 \%$, promoting total epidermolysis, keratinocytes separation and formation of new elastin and collagen fibers (Balbinot \& Agnes, 2012).

It was possible to emphasize, by analyzing the obtained results, among the major frequency active substances, the kojic acid, arbutin, ascorbic acid and hydroquinone were the ones that act inhibiting the tyrosinase enzyme. Meanwhile, glycolic acid promotes peeling and stimulates new skin cells synthesis, therefore, reducing hyperpigmentation appearance (Balbinot \& Agnes, 2012).

The literature consulted presents other mechanisms of hyperchromia reduction. Among them, it is possible to stand out the following examples (Gold \& Biron, 2011; Hirokawa \& Noda, 2008):

- melanocytes de-characterization or destruction, by antioxidants compounds, that will alter metabolic reactions by oxygen depletion;

- interference in the biosynthesis of melanin and its precursors; 
- tyrosinase inhibition or inactivation;

- interference in the transport of melanin granules to keratinocytes;

- alteration (reduction) of brown melanin present in melanosomes (oxidized form) to a lighter coloration (reduced form).

During this study, it was possible to identify other actives substances on researched products. In addition, other ingredients acting by tyrosinase enzyme inhibition were found, such as mandelic acid, phytic acid, and bearberry extract. Bearberry extract acts degrading the existing skin melanin. Retinoic acid, also called vitamin A or tretinoin was found in $8 \%$ of the studied products. This ingredient acts dispersing melanin granules inside keratinocytes, interfering on melanosomes transfer and accelerating cellular renewal. Dioic acid, which was found in one product, acts by reducing tyrosinase enzyme production mechanism (Cesário, 2015; Franco et al., 2012; Neves, 2013).

\subsection{The combination of depigmenting actives}

Depigmenting agents' combination may happen among active substances, which present the same mechanisms, thus intensifying their actions, or among depigmenting agents with differentiated mechanisms of action. Active substances combination aims for products effectiveness, leading to greater chemical stability and faster and longer results to the patient. It is important to emphasize that a special care is required, once each substance has its own characteristics, and it is important to verify possible active combinations in order to maintain physical-chemical characteristics and formulation stability related to therapeutic, toxicological and microbiological aspects (Costa et al., 2010; Martins \& Oliveira, 2015).

The most commonly active combination found ( $20 \%$ of the products) was glycolic acid with actives substances that inhibit action of tyrosinase enzyme, for example kojic acid or hydroquinone. Glycolic acid has exfoliating action reducing excessive pigmentation caused by hypermelogenis in affected areas (Gonchorosk \& Corrêa, 2005; Gold \& Biron, 2011). Its association with kojic acid and hydroquinone makes these ingredients more potent due to the capacity of glycolic acid to reduce the corneal layer and softens cellular cement increasing skin permeation and optimizing the bleaching effect (Martins \& Oliveira, 2015; Steiner et al., 2009).

The present study also allowed to evidence depigmenting actives combined with exfoliating agents. This observation may be related with the fact that exfoliators can reduce epidermis thickness favoring other actives substances permeability. In addition, by mechanical action it is possible to remove skin superficial pigmentations (Martins \& Oliveira, 2015; Neves, 2013).

Another combination found was among hydroquinone, tretinoin and fluocinolone acetonide. Fluocinolone is a corticosteroid classified as anti-inflammatory and tretinoin has keratolytic activity. The association such ingredients was verified in $9 \%$ of researched products. Studies have shown that hydroquinone and retinoic acid effect is optimized when both are used in combination with corticosteroids such as fluocinolone, for example (Cestari et al., 2007a; Chan et al., 2008; Cestari et al., 2007b; Grimes, 2007).

Triple combination regimen is more effective first-line treatment for melasma than monotherapies with a bleaching agent acting alone (Godse, 2009; Shankar et al., 2014). The combination of hydroquinone, retinoic acid and a topical steroid in concentrations of $5 \%, 0.1 \%$ and $0.1 \%$, respectively, is capable of enhance the efficacy of each active substance, shortening the duration of therapy and reducing the risk of adverse effects (Torok et al., 2005). Tretinoin, or retinoic acid, prevents hydroquinone oxidation and favors epidermal penetration while the steroid reduces skin irritation caused by the other two active substances. The steroid also suppresses biosynthetic and secretory functions of melanocytes, leading to an early response in melasma (Godse, 2009; Shankar et al., 2014).

The US Food and Drug Administration have approved the combination of $4 \%$ hydroquinone, $0.05 \%$ tretinoin and $0.01 \%$ fluocinolone acetonide for the treatment of 
melasma (Torok et al., 2005; Torok, 2006). The safety and efficacy of the combination was assured to be superior to 12 weeks not causing skin atrophy or severe adverse effects (Shankar et al., 2014).

\subsection{Formulations vehicles}

Regarding the use of emulsified vehicles under cream form, the observed preference by the manufacturers may be attributed to the easy incorporation of active substances into this system, mainly due to biphasic structure (hydrophilic/ lipophilic), better dissolved ingredients distribution in droplets of internal phase and spreadabillity on skin surface (Estanqueiro et al., 2016; Montenegro et al., 2015).

Creams are emulsified systems of semisolid consistency, composed by two phases: one lipophilic and another hydrophilic, being each phase dispersed into another by action of an emulsifier. Emulsions allow hydrophilic or lipophilic substances incorporation, are stable formulations in a wide $\mathrm{pH}$ range and are easy to apply. Hydrophilic gels are aqueous systems that present limitations on lipophilic active substances incorporation. It is a system suitable for greasy skins and has stability over a wide $\mathrm{pH}$ range and easy application (Brasil, 2005c).

Considered as a relatively new semisolid form, gel-creams are oil-in-water systems containing a polymeric solution as thickened aqueous external phase (Rosa et al., 2016). Gelcreams have arisen as an alternative in order to diminish the amount of lipids in the formulation in the presence of lipophilic active substances and when patient exhibits greasy skin.

Serum was another kind of vehicle found in this research. This vehicle presents superior fluidity than the other vehicles found and thus it stands out for providing a faster skin penetration. Moreover, this vehicle is usually used for treating eyes area and in addition, the hyperchromias, the active substances combination may lead to expression lines attenuation.

\subsection{Label information}

\subsubsection{Anti-aging action}

Cutaneous hyperchromia may be related to the advancement of patient's age, as well as genetic, hormonal and sun exposure factors. Thus, it is useful to combine with depigmenting agents, anti-aging active substances in order to make possible hyperchromia treatment and preventing signs of aging. The anti-aging agents found were hyaluronic acid, retinaldehyde, vitamin E and several plant extracts presenting antioxidant action (Neves, 2013).

\subsubsection{Sunscreen}

Ultraviolet (UV) radiation has a very significant effect on the appearance of cutaneous hyperchromia. It happens because UVA rays oxidize and darken the colorless melanin precursors and UVB rays multiply active melanocytes and stimulate melanin synthesis. Patients undergoing hyperchromia treatment must be advised to protect their skin from the sun with extreme caution by using high protection sunscreens ( $\geq$ SPF 30) in order to obtain the expected treatment result. In addition, during the use of products with depigmenting action, the skin becomes more sensitive and can suffer damage by solar radiation. This is considered a strong reason to use sunscreen throughout treatment. During summer, it is usual that patients undergoing hyperchromia treatment, and who have used depigmenting agents during winter, present resections (Neves, 2013; Silva, 2013).

By means of the above mentioned, it can be concluded that there are several formulations with depigmenting agents currently on the market. The researched products presented, mainly, the combination of active substances with depigmenting action through the synergism of different mechanisms. The use of active substances consecrated by depigmenting action and the absence of new depigmenting substances with such purpose 
was also observed. In addition, in order to achieve the best results, it is essential the patient's guidance by healthcare professionals to provide the necessary care, especially concerning about sun exposure, during the use of cosmetics or medication with depigmenting action.

\section{REFERENCES}

Balbinot F, Agnes EJ. Avaliação da estabilidade físico-química de emulsões contendo associação de ácido glicólico e hidroquinona [trabalho de conclusão de curso]. Criciúma: Universidade do Extremo Sul Catarinense; 2012.

Baron JM, Skazik C. Research in practice: the second barrier of the human skin. J Dtsch Dermatol Ges. 2010;8(3):155-8. http://dx.doi.org/10.1111/j.1610-0387.2009.07217_supp.x. PMid:19751223.

Brasil. Agência Nacional de Vigilância Sanitária. Câmara Técnica de Cosméticos. Parecer Técnico $n^{\circ} 3$ : Utilização de vitamina C em produtos cosméticos. Brasília; 29 jun 2001.

Brasil. Agência Nacional de Vigilância Sanitária. Resolução no 211, de 14 e julho de 2005. Estabelece a Definição e a Classificação de Produtos de Higiene Pessoal, Cosméticos e Perfumes, conforme Anexo I e II desta Resolução e dá outras definições. Diário Oficial da União; Brasília; 18 jul 2005a.

Brasil. Agência Nacional de Vigilância Sanitária. Resolução no 343, de 13 e dezembro de 2005. Institui novo procedimento totalmente eletrônico para a Notificação de Produtos de Higiene Pessoal, Cosméticos e Perfumes de Grau 1 e dá outras providências. Diário Oficial da União; Brasília; 15 dez 2005b.

Brasil. Ministério da Saúde. Agência Nacional de Vigilância Sanitária. Formulário naciona. Brasília: Ministério da Saúde, 2005c.

Brasil. Ministério da Saúde. Agência Nacional de Vigilância Sanitária. Resolução n 67 , de 8 de outubro de 2007. Dispõe sobre Boas Práticas de Manipulação de Preparações Magistrais e Oficinais para Uso Humano em farmácias. Diário Oficial da União; Brasília; 9 out 2007.

Brasil. Agência Nacional de Vigilância Sanitária. Guia prático para identificação de medicamentos irregulares no mercado. Brasília: ANVISA; 2010. 24 p.

Brasil. Agência Nacional de Vigilância Sanitária. RDC n 7, 10 de fevereiro de 2015. Dispõe sobre os requisitos técnicos para a regularização de produtos de higiene pessoal, cosméticos e perfumes e dá outras providências. Diário Oficial da União; Brasília; 11 fev. 2015.

Brener $M$, Hearing $\mathrm{VJ}$. What are melanocytes really doing all day long...? : from the ViewPoint of a keratinocyte: Melanocytes - cells with a secret identity and incomparable abilities. Exp Dermatol. 2009;18(9):799-819.

Cesário GR. Principais ativos utilizados no tratamento do melasma [trabalho de conclusão de curso]. Palmas: Centro Universitário Luterano de Palmas; 2015.

Cestari T, Adjadj L, Hux M, Shimizu MR, Rives VP. Cost-effectiveness of a fixed combination of hydroquinone/tretinoin/fluocinolone cream compared with hydroquinone alone in the treatment of melasma. J Drugs Dermatol. 2007a;6(2):153-60. PMid:17373174.

Cestari TF, Hassun K, Sittart A, Viegas ML. A comparison of triple combination cream and hydroquinone $4 \%$ cream for the treatment of moderate to severe facial melasma. J Cosmet Dermatol. 2007b;6(1):36-9. http://dx.doi.org/10.1111/j.1473-2165.2007.00288.x. PMid:17348994.

Chan R, Park KC, Lee MH, Lee ES, Chang SE, Leow YH, Tay YK, Legarda-Montinola F, Tsai RY, Tsai TH, Shek S, Kerrouche N, Thomas G, Verallo-Rowell V. A randomized controlled trial of the efficacy and safety of a fixed triple combination (fluocinolone acetonide $0.01 \%$, hydroquinone $4 \%$, tretinoin $0.05 \%$ ) compared with hydroquinone $4 \%$ cream in Asian patients with moderate to severe melasma. Br J Dermatol. 2008;159(3):697-703. PMid:18616780.

Costa A, Moisés TA, Cordero T, Alves CR, Marmirori J. Associação de emblica, licorice e belides como alternative à hidroquinona no tratamento clínico do melasma. An Bras Dermatol. 2010;85(5):61320. http://dx.doi.org/10.1590/S0365-05962010000500003. PMid:21152784.

Costa A, Arruda LHF, Pereira ESP, Pereira MO, Santos FBC, Fávaro R. Estudo clínico para a avaliação das propriedades clareadoras da associação de ácido kójico, arbutin, sepiwhite ${ }^{\circledR}$ e achromaxyl ${ }^{\circledR}$ na abordagem do melasma, comparada à hidroquinona 2\% e 4\%. Surg Cosmet Dermatol. 2012;3:22-30.

Costin G-E, Hearing VJ. Human skin pigmentation: melanocytes modulate skin color in response to stress. FASEB J. 2007;21(4):976-94. http://dx.doi.org/10.1096/fj.06-6649rev. PMid:17242160. 
Estanqueiro M, Amaral MH, Sousa Lobo JM. Comparison between sensory and instrumental characterization of topical formulations: impact of thickening agentes. Int J Cosmet Sci. 2016;38(4):389-98. http://dx.doi.org/10.1111/ics.12302. PMid:26700373.

Food and Drug Administration - FDA. Department of Health and Human Services. Skin bleaching drug products for overthe- counter human use; proposed rule. Fed Regist. 2006;71:51146-55.

Franco DCZ, Carvalho GSG, Rocha PR, Teixeira RS, Silva AD, Raposo NRB. Inhibitory effects of resveratrol analogs on mushroom tyrosinase activity. Molecules. 2012;17(10):11816-25. http://dx.doi.org/10.3390/molecules171011816. PMid:23047482.

Frasson APZ, Canssi CM. Análise da qualidade de cremes com hidroquinona 2\% manipulados no município de ljuí/RS. Rev Cienc Farm Basica Apl. 2009;29(2):197-201.

Gaedtke GN. Abordagem terapêutica do melasma na gestação - revisão bibliográfica [trabalho de conclusão de curso]. Curitiba: Universidade Tuiuti do Paraná; 2011.

Godse KV. Triple combination of hydroquinone, tretinoin and mometasone furoate with glycolic acid peels in melasma. Indian J Dermatol. 2009;54(1):92-3. http://dx.doi.org/10.4103/0019-5154.49005. PMid:20049286.

Gold MH, Biron J. Efficacy of a novel hydroquinone-free skin-brightening cream in patients with melisma. J Cosmet Dermatol. 2011;10(3):189-96. http://dx.doi.org/10.1111/j.14732165.2011.00573.x. PMid:21896130.

Gonchoroski DD, Côrrea GM. Tratamento de hipercromia pós-inflamatória com diferentes formulações clareadoras. Infarma. 2005;17(3/4):84-8.

Grimes PE. An efficacy study of 3 commercially available hydroquinone $4 \%$ treatments for melasma. Cutis. 2007;80(6):497-502. PMid:18246882.

Hirokawa N, Noda Y. Intracellular transport and kinesin superfamily proteins, KIFs: structure, function, and dynamics. Physiol Rev. 2008;88(3):1089-118. http://dx.doi.org/10.1152/physrev.00023.2007. PMid:18626067.

Lopes AAS. Inibidores de tirosinase e novas técnicas laboratoriais de separação de produtos naturais bioactivos. [dissertação]. Lisboa: Escola de Ciências e Tecnologias da Saúde, Universidade Lusófona de Humanidades e Tecnologias; 2015.

Marques LAM, Sasai LCS, Musa LF. Preparación de un modelo de atención farmacéutica a los usuarios de formulas magistrales con despigmentantes cutáneos. Rev Eletronica Farm. 2011;VIII(2):108-20.

Martins VCS, Oliveira SP. Estudo dos benefícios do tratamento de melasma por intermédio do ácido kójico associado ao ácido glicólico [trabalho de conclusão de curso]. [Curitiba]: Universidade Tuiuti do Paraná; 2015.

Miot LDB, Miot HA, Silva MG, Marques MEA. Estudo comparativo morfofuncional de melanócitos em lesões de melasma. An Bras Dermatol. 2007;82(6):529-34. http://dx.doi.org/10.1590/S036505962007000600005.

Monteiro RC, Kishore BN, Bhat RM, Sukumar D, Martis J, Ganesh HK. A Comparative Study of the Efficacy of $4 \%$ Hydroquinone vs $0.75 \%$ Kojic Acid Cream in the Treatment of Facial Melasma. Indian J Dermatol. 2013;58(2):157. http://dx.doi.org/10.4103/0019-5154.108070. PMid:23716817.

Montenegro L, Rapisarda L, Ministeri C, Puglisi G. Effects of lipids and emulsifiers on the physicochemical and sensory properties of cosmetic emulsions containing vitamin E. Cosmetics. 2015;2(1):35-47. http://dx.doi.org/10.3390/cosmetics2010035.

Neves BP. Revisão de literatura sobre melasma: enfoque no tratamento [trabalho de conclusão de curso]. Alfenas: Faculdades Unidas do Norte de Minas, Instituto de Ciências da Saúde; 2013.

Reszko AE, Berson D, Lupo MP. Cosmeceuticals: practical applications. Dermatol Clin. 2009;27(4):40116, v. http://dx.doi.org/10.1016/j.det.2009.08.005. PMid:19850190.

Rosa P, Santos JD, Lehmen TF, Weber J, Flores FC, Silva CB, Oliveira SM, Brusco I, Milani GB, Adams AI. In vitro and in vivo evaluation of a desonide gel-cream photostabilized with benzophenone-3. Drug Dev Ind Pharm. 2016;42(1):19-27. http://dx.doi.org/10.3109/03639045.2015.1022554. PMid:25775013.

Scientific Committee on Consumer Products - SCCP. Opinion on kojic acid [Internet]. União Européia: EU; 2008 [cited 2010 Sep 20]. Available from: http://ec.europa.eu/health/ph_risk/committees/04_sccp/docs/sccp_o_148.pdf 
Shankar K, Godse K, Aurangabadkar S, Lahiri K, Mysore V, Ganjoo A, Vedamurty M, Kohli M, Sharad J, Kadhe G, Ahirrao P, Narayanan V, Motlekar SA. Evidence-based treatment for melasma: expert opinion and a review. Dermatol Ther (Heidelb). 2014;4(2):165-86. http://dx.doi.org/10.1007/s13555014-0064-z. PMid:25269451.

Silva DPP. Nanopartículas lipídicas: aplicações cosméticas [dissertação de mestrado]. Porto: Universidade de Fernando Pessoa, Faculdade de Ciências da Saúde; 2013.

Steiner D, Feola C, Bialeski N, Morais e Silva FA. Tratamento do melasma: revisão sistemática. Surg Cosmet Dermatol. 2009;1(2):87-94.

Torok H, Taylor S, Baumann L, Jones T, Wieder J, Lowe N, Jarret M, Rich P, Pariser D, Tschen E, Martin D, Menter A, Weiss J. A large 12-month extension study of an 8-week trial to evaluate the safety and efficacy of triple combination (TC) cream in melasma patients previously treated with TC cream or one of its dyads. J Drugs Dermatol. 2005;4(5):592-7. PMid:16167418.

Torok HM. A comprehensive review of the long-term and short-term treatment of melasma with a triple combination cream. Am J Clin Dermatol. 2006;7(4):223-30. http://dx.doi.org/10.2165/00128071200607040-00003. PMid:16901182.

Tortora GJ, Derrickson B. Corpo humano: fundamentos de anatomia e fisiologia. 8. ed. Porto Alegre: ArtMed; 2012

Uchida R, Ishikawa S, Tomoda H. Inhibition of tyrosinase activity and melanine pigmentation by 2hydroxytyrosol. Acta Pharm Sin B. 2014;4(2):141-5. http://dx.doi.org/10.1016/j.apsb.2013.12.008. PMid:26579376.

Videira IFS, Moura DFL, Magina S. Mechanisms regulating melanogenesis. An Bras Dermatol. 2013;88(1):76-83. http://dx.doi.org/10.1590/S0365-05962013000100009. PMid:23539007.

\section{Author contributions}

Rotava PA: conceptualization, funding acquisition, supervision, writing; Garcia KR;Weiss-Angeli V: conceptualization, data curation, formal analysis, methodology, writing; Weiss-Angeli V.; Favero JS: data curation, formal analysis. 